\title{
All write: Samarbeid om skriving i engelskopplæringen
}

Ragnhild Elisabeth Lund

Høgskolen i Buskerud og Vestfold

\section{Abstract}

Denne artikkelen tar for seg elevers samarbeid om skriving i engelskfaget, innenfor rammen av et kurstilbud for svakt presterende elever på åttende, niende og tiende trinn. Læreren vektla skriveaktiviteter i disse kursene med referanse til Swain \& Lapkin (1995) sin «output hypothesis», som går ut på at elever lærer best når de må produsere språk selv. Idéen til samarbeidsskriving fikk han fra forskning som peker på språklæringseffekten av at elever snakker sammen om språk («languaging») og blir klar over «hull» («gaps») i egne språkferdigheter (Swain 2006; Manchón 2011a). Skriving anses som spesielt egnet for «languaging», ettersom skriftlig språk produseres langsommere enn muntlig, og fordi elevene kan forholde seg til et skriftlig produkt (Williams, 2012). Jeg var følgeforsker ved kursene.

Undersøkelsen viser at elevene opplevde samarbeid om skriving som motiverende og lærerikt. De la stor arbeidsvilje for dagen, og de samarbeidet både om innhold, tekststruktur og språklige utfordringer. Bearbeiding av tekst på bakgrunn av lærerens tilbakemeldinger viste seg å være spesielt godt egnet for samarbeid.

Overkommelige, meningsfylte og varierte oppgaver ser ut til å være en viktig forutsetning for at elevene skal trives med samarbeidsformen. Lærerens faglige og administrative dyktighet og evne til å motivere og å skape et trygt læringsmiljø spiller også en avgjørende rolle.

\section{Innledning}

Denne artikkelen tar for seg et undervisningsopplegg der elevene samarbeidet om ulike skriveaktiviteter i engelskopplæringen. Elevene var svakt presterende elever på ungdomstrinnet som fikk tilbud om ekstra undervisning i mindre grupper. Læreren $\emptyset$ nsket å undersøke om de kunne bli motivert for å gjøre en ekstra innsats når det gjaldt engelsk generelt og skriving spesielt dersom de samarbeidet om ulike typer skriveoppgaver. Jeg var følgeforsker og observerte undervisningen. Jeg foretok dessuten flere intervjuer, både med elevene og læreren.

\section{Bakgrunn}

Læreplanen for engelsk omtaler skriving både som et mål og et middel. Elevene skal lære å uttrykke seg skriftlig på engelsk gjennom ulike typer tekster. Samtidig slår planen fast at skriving er «et redskap for språklæring» (Utdanningsdirektoratet 2013). De to dimensjonene omtales ofte som å lare å skrive og å skrive for å lare (Manchón 2011b).

Elevene som denne artikkelen handler om, hadde i utgangspunktet stor motvilje mot å skrive engelsk. Tekstene de produserte vitnet om minimal innsats og svært mangelfulle språkferdigheter. Læreren jeg observerte, som jeg kaller Per, anså imidlertid skriving som en sentral aktivitet i språklæringsprosessen, og han ønsket å hjelpe elevene både med å skrive for å lace og å laere å skrive. Basert på et sosiokulturelt læringssyn ønsket han å få til samarbeid og språklig interaksjon i klasserommet, med høy grad av elevaktivitet. Han kjente til 
forskning som viser at samskriving («collaborative writing») kan ha positiv effekt både når det gjelder motivasjon og tekstproduksjon, og han ønsket derfor å utforske hvilke muligheter samarbeid om skriving kunne ha i hans egne elevgrupper.

Per hadde fått $\mathrm{i}$ oppdrag å gjennomføre tre kursrekker, ett for hvert av trinnene i ungdomsskolen. Pers skole har hatt gode erfaringer med å prøve å fange opp elever som sliter med ulike fag på et tidligere tidspunkt enn Ny Giv-satsingen legger opp til. Tilbudet om kurs blir gitt etter en helhetlig vurdering av hver enkelt elev, i samråd med foreldrene. Elevene har i gjennomsnitt oppnådd mestringsnivå 1 og 2 ved de nasjonale prøvene, og ingen av dem har krav på spesialunderundervisning. Jeg fulgte alle de tre gruppene, som besto av til sammen 23 elever.

Det er forsket mye på skriving i fremmedspråkopplæringen. Mange unders $ø$ kelser handler, ikke uventet, om hvordan en best skal kunne hjelpe elevene med å utvikle skriftlige ferdigheter. Vektlegging av grammatikkundervisning og sjangerkunnskap og ulike former for tilbakemelding er bare noen av stikkordene her (se for eksempel Kroll 2001; Hyland \& Hyland 2006). I den senere tid er det skrevet mye om de ulike formål og funksjoner skriveaktiviteter kan ha, og den norske læreplanens skille mellom å lare å skrive og å skrive for å lare reflekterer denne forskningen (se for eksempel Manchón 2009; Manchón 2011b). Ulike former for støtte i skriveprosessen og ulike måter å organisere skriveopplæringen på (eksempelvis i form av samarbeid) er også behørig beskrevet i internasjonale publikasjoner (se for eksempel Ali 2013; Storch 2005).

I Norge er det imidlertid forsket lite på skriving i engelsk- og fremmedspråkopplæringen. Studier finnes av lærerstudenters kompetanse når det gjelder undervisning i skriving (Drew 1998) og om elevers arbeid med narrative tekster i et internasjonalt nettverk (Larsen 2009). Noen mindre undersøkelser er gjort av skriftlige oppgaver i engelsklæreverk (Lia 2001; Lund 2013) og av formelle sider ved elevers skriftlige produksjon (Raaen \& Guldal 2012). Hva støtte i skriveprosessen angår, viser Langseth (2012) hvordan ulike former for stillasbygging kan være læringsfremmende så vel som motiverende for fremmedspråkelevers arbeid med skriving. Oddvik (2011) beskriver hvordan samarbeid om skriveaktiviteter ved hjelp av datamaskin ser ut til å motivere elever til innsats $\mathrm{i}$ engelskopplæringen. Dette er, meg bekjent, den eneste undersøkelsen som er gjort i Norge av elevers samarbeid om skriving i et språkfag. Forskning på skriving som en grunnleggende ferdighet og som et verktøy i språklæringsprosessen ser også ut til å være mangelvare, til tross for læreplanens vektlegging av denne dimensjonen ved skriving.

Jeg ønsket derfor å bidra til mer kunnskap om hvordan elever kan lære å skrive i engelskfaget og hvordan skriving kan utnyttes som et redskap i språklæringsprosessen. Spesifikt $\emptyset$ nsket jeg å unders $\varnothing$ ke hvordan samarbeid om skriving kan fungere i grupper med svake elever, og jeg formulerte følgende forskningsspørsmål:

Hvordan kan skrivesamarbeid benyttes i grupper med svake elever for å fremme elevaktivitet, læring og en mer positiv holdning til faget?

\section{Teoretisk rammeverk}

Undervisningsopplegget og diskusjonen av det tar utgangspunkt i et sosiokulturelt syn på fremmedspråklæring, der interaksjon og ikke minst språklig samhandling anses som vesentlige faktorer i opplæringssituasjonen (Lightbown \& Spada 2006). En forutsetning for læring er at oppgavene ligger innenfor elevenes nærmeste utviklingssone og at medelever og lærer(e) kan gi støtte i læringsprosessen (Vygotsky 1978). Elevenes motivasjon for læring forventes å øke når de kan ta del i et læringsmiljø der de blir verdsatt, føler seg hjemme og opplever mestring (Roeser, Eccles \& Sameroff 2000). Lærerens evne til å oppnå elevenes tillit anses som helt sentral når det gjelder å skape et inkluderende læringsfellesskap (Gregory \& Ripski 2008). 
Vektleggingen av skriving er basert på Swain \& Lapkin (1995) sin «output hypothesis», som går ut på at elevenes språklæring stimuleres i særlig grad når de må produsere tekst selv. Når elevene bruker språket vil de kunne bli oppmerksomme på «hull» («gaps») i egen språkkompetanse, noe som er en forutsetning for videre utvikling (Manchón 2011a). Dette er altså en annen type skriving enn de mekaniske utfyllingsoppgavene som tradisjonelt har hatt en framtredende plass i fremmedspråkopplæringen (Hyland 1996).

Vektleggingen av samarbeid om skriveoppgaver er basert på Swain (2006) sin teori om «languaging». Den går ut på at elevene kan prøve ut og få feedback på språket sitt gjennom samtale og interaksjon, og at samarbeid og refleksjon rundt egen og andres språklige produksjon vil kunne utgjøre et vesentlig element i språklæringsprosessen. Forskning viser at samarbeid om skriving fører til mer elevaktivitet, og det er grunn til å tro at elevenes diskusjoner og felles stillasbygging vil føre til bedre læring (Wigglesworth \& Storch 2012). Forskning viser også at mange elever opplever skrivesamarbeid som motiverende og lærerikt (Shehadeh 2011). Det sosiale fellesskapet og «the power of the peer» spiller nok en avgjørende rolle her. John Hattie sier det slik: «If you want to increase student academic achievement, give each student a friend» (Hattie 2009, 214).

En kan hevde at skriftlige tekster er spesielt godt egnet for «languaging», både fordi elevene har et skriftlig produkt å forholde seg til og fordi de har bedre tid til rådighet i en skrivesituasjon enn i en talesituasjon. I tillegg stilles det oftest større krav til presisjon i en skriftlig enn en muntlig tekst (Williams 2012). Samtidig er det viktig å være klar over hva slags oppgaver en gir. Størst læringsutbytte får en trolig dersom oppgaven oppfordrer til refleksjon over og kommunikasjon om hvordan noe best kan uttrykkes. Det viktigste er likevel at eleven blir engasjert, enten fordi oppgaven er relevant og interessant i seg selv, eller fordi den inngår som et autentisk element i den sosiale settingen der elevene befinner seg (Williams 2012).

Mye er skrevet om «retting» og ulike typer tilbakemelding på elevers skriftlige arbeider, og en rekke forskningsprosjekter sår tvil om effekten særlig av lærerens feedback (Truscott 1996; 2007). Samtidig viser forskning at elever forventer og verdsetter lærerens tilbakemeldinger (Hyland 2011). En forutsetning for at læring skal skje ser imidlertid ut til å være at elevene merker seg innholdet i tilbakemeldingen og bearbeider den på ett eller annet vis (Sachs \& Polio 2007). Det er særlig her at prinsippet om samarbeid og «languaging» kan komme inn (Wigglesworth \& Storch 2012).

\section{Metodologi/forskingsdesign}

Kursene for åttende og niende trinn består av to timer per uke i fem uker og blir avviklet $\mathrm{i}$ høstsemesteret. Kurset for niende trinn blir gjennomført først, ettersom skolen allerede kjenner disse elevene fra åttende trinn, der de blant annet har gjennomført nasjonale prøver. Tilbudet for tiende trinn er et ledd i Ny Giv-satsingen og varer hele vårhalvåret, med to timer ekstra engelsk per uke. Gruppene jeg fulgte besto av henholdsvis åtte, seks og ni elever.

Jeg observerte to av øktene på niende trinn, fem på åttende og seks på tiende trinn. Det var i hovedsak i disse $\varnothing$ ktene at elevene samarbeidet om skriving. Aktivitetene omfattet både samskriving, oppgaver der elevene ble satt i par eller grupper på tre og skulle produsere en tekst sammen, og samarbeid om å rette opp og videreutvikle ulike tekster. Jeg lyttet så godt og så diskret - jeg kunne til de ulike gruppene og skrev ned utdrag fra elevenes samtaler. I tillegg noterte jeg meg hvilke oppgaver som lot til å slå an og hvilke aspekter ved skrivingen elevene særlig så ut til å samarbeide om. Alle elevene ble intervjuet underveis og etter kurset om erfaringene deres med samarbeidet og med skrivingen. I tillegg til å intervjue hele gruppa på hvert trinn samlet, snakket jeg også med noen av elevene enkeltvis. Både elevene, deres foreldre og skolens ledere hadde gitt sin tillatelse til dette. Per ga meg løpende informasjon 
om hva han ønsket å oppnå med de ulike aktivitetene han satte i gang og om sine vurderinger i etterkant. I tillegg intervjuet jeg ham to ganger, ved slutten av hvert semester.

\section{Oppgavene}

Elevene innså at det er nødvendig å lære å skrive engelsk, både med tanke på skriftlig tentamen / eksamen og framtidige jobber. Samtidig var de klare på at det er skriving de sliter mest med. «Det går mye bedre å prate» og «skriving suger»var typiske utsagn. Flere av elevene knyttet dette til tidligere skriveerfaringer, der de ofte hadde opplevd at oppgavene var lite fengende: «Det var sånn «Sett dere ned og skriv en tekst», i stedet for å gjøre noe morsommere ut av å skrive teksten». De slet selvsagt også med «å bøye alle de ordene og sånn». Ettersom de var negative til å skrive i utgangspunktet, var det først i siste intervjurunde at elevene hadde noe positivt å si om skriving som et redskap for språklæring.

Per var fullt klar over det han beskrev som «elevenes indre motstand» mot å skrive engelsk, som han regnet med bunnet i mange tidligere opplevelser av nederlag. Hans strategi var derfor å starte med oppgaver som han var sikker på at elevene ville mestre. Han la også stor vekt på å la elevene skrive tekster «om motiverende og artige ting», som anbefalt $\mathrm{i}$ forskningslitteraturen (jfr Williams 2012). Mekaniske utfyllingsoppgaver inngikk ikke i hans repertoar.

Strategien hans så ut til å fungere godt. Per brukte for eksempel sanger, både som utgangspunkt for utfyllingsoppgaver og for elevenes korte tekster om hva de mente sangen handlet om. Utfyllingsoppgavene var «cloze tests» eller basert på lytting. Andre oppgaver bygget på tekster elevene hadde lest og filmer de hadde sett. Tenåringsproblematikken som blir tatt opp i boka Diary of a Wimpy Kid (som alle elevene på åttende trinn leste) og filmen Juno (som elevene på tiende trinn så) var nok spesielt relevant for elevene og resulterte i flere ulike skriveaktiviteter. Elevene ble også bedt om å skrive et kort innlegg i dagboka til kjente karakterer som Spiderman, Batman og Bella Swan (fra Twilight-serien), og de fikk i oppgave å diskutere aktuelle problemstillinger som denne: «A lot of parents pay their kids money for good grades. Is this a good idea?»

Den eneste oppgaven som slett ikke fungerte, var fjorårets eksamensoppgave som elevene på tiende trinn fikk som trening uka før tentamen. Elevene hadde lest en tekst $\mathrm{i}$ forberedelsesheftet før timen (et utdrag fra boka The Immortal Life of Henrietta Lacks), men skjønte åpenbart svært lite av den. Oppgaven gikk ut på å skrive om teksten med en alternativ fortellerstemme, en vanskelig oppgave som elevene brukte all sin energi på å klage og raljere over. Per greide ikke å motivere dem for å komme i gang, og ingen av elevene skrev mer enn en kort setning i løpet av denne timen.

I intervjuene snakket elevene en hel del om betydningen av at Per ga dem motiverende og varierte skriveoppgaver, og utsagn som disse gikk igjen:

- Her har vi så mye gøye oppgaver. Per gjør det så gøy, og da blir det mye triveligere å være her og en får mye mer lyst til å lære.

- For eksempel første gangen da vi hadde en sånn sang og skulle plassere ordene, det syntes jeg var gøy. Ikke bare skrive en fortelling på flere sider og sånn og sitte og jobbe med boka.

- Det jeg synes Per er veldig god til er at han gjør det morsomt samtidig som vi lærer noe. At det ikke bare blir morsomt. Eller bare læring.

\section{Samarbeid om å læere å skrive}

Observasjonene viste at skrivingen var atskillig mer lystbetont og at elevene greide å produsere mer tekst når de satt sammen enn når de av og til hadde individuelle skriveoppgaver. To gutter som tidligere ifølge læreren knapt hadde vært villige til å skrive noe 
som helst gikk løs på en oppgave med iver og glød etter å ha sett en del av filmen Juno. Filmen handler om en tenåringsjente som ikke får seg til å ta abort, og oppgaven gikk ut på å skrive i dagboka hennes, med støtte i en skriveramme. Dette er noe av resultatet (elevenes skriving er i kursiv):

\begin{tabular}{|l|}
\hline Dear Diary! Today I told my father and step-mom that I'm pregnant \\
\hline At first they whas lik WTF and askt for the dady \\
\hline But then they laft \\
\hline My step-mom said you are a Viking \\
\hline I had been expecting an aboruson but I cudent do it. \\
\hline$[\ldots]$
\end{tabular}

Elevene hjalp hverandre både med å komme i gang og med å komme videre med tekstene sine. Da Ida og Kim skulle drøfte om det er lurt av foreldre å belønne barna for gode karakterer, brukte de kort tid på å bli enige om sitt første poeng: «We don’t think this is a problem. Many kids will work much harder if they get money.» Så stoppet det opp, før de begynte å diskutere videre:

Ida: Nå må vi ha et motargument.

Kim: Å ja, det er sant. Kanskje noe om at...

Ida: Jeg synes jo bare det er fint, jeg.

Kim: Ja, men vi må jo ha et motargument.

Ida og Kim diskuterte altså hvilket innhold de ønsket å ha med i teksten sin, i tillegg til at de hjalp hverandre med å imøtekomme sjangerkravene. De hadde gitt seg i kast med en drøftingsoppgave, og de hadde lært tidligere at slike oppgaver krevde argumenter både for og imot en sak før de til slutt kunne konkludere.

Jeg observerte også flere ganger at elevene hjalp hverandre med å konstruere gode avsnitt. Etter at Ole og Marius hadde sittet en stund og skrevet hver sin setning i en felles tekst, for eksempel, hørte jeg følgende replikkutveksling:

Ole: Is this a paragraph?

Marius: No. It's a lot of random sentences.

De lo, og begynte å stokke om på setningene så det ble bedre sammenheng.

Per la stor vekt på å gi elevene støtte underveis i skriveprosessen, og han var godt orientert om forskning som viser betydningen av dette. Oppgaver som krevde mer enn et kort avsnitt var som regel utstyrt med skriverammer som elevene kunne støtte seg til. Da elevene skulle skrive en kort rapport om ei bok de hadde lest, fikk de denne rammen:

\begin{tabular}{|l|}
\hline The title of the book is \\
It is written by \\
\hline The book is about .... \\
In addition, we also learn .... \\
\hline I like this book for several reasons, firstly .... \\
Secondly, .... \\
Thirdly, ... \\
\hline However, I did not like .... \\
\hline The book is suitable for .... \\
\hline To sum up, I think .... \\
\hline
\end{tabular}


Skriverammene bidro helt klart til at elevene skrev mer enn de ellers ville gjort. Avsnittet der de skulle forklare hva de likte ved boka, for eksempel, førte til at hele gruppa la seg i selen og greide å formulere tre ulike grunner til at de likte den.

Jeg spurte elevene om de likte å jobbe med skriverammer, og jeg fikk bare positive svar. Utsagnene til tre jenter på åttende trinn var representative:

- Ja, da vet vi hva vi skal skrive om.

- Det blir litt enklere å fortsette på en måte, og vite hva en skal skrive.

- Vi kan bare fortsette på setningen, liksom. Og så blir det ikke bare å velge lette løsninger.

Det er interessant å se at to av jentene snakker om skriverammen som en støtte som gjør det lettere for dem å skrive, mens den tredje påpeker at skriverammene også kan tvinge elevene til å skrive mer avanserte tekster. Et hovedpoeng ved skriverammer er jo at elevene kan bruke dem både som skrivestøtte og som utgangspunkt for refleksjon over hvordan tekster kan bygges opp. Gradvis vil de kunne lære seg å skrive uten dem (Lewis \& Wray 2002).

I intervjuene fortalte elevene at det var fint å kunne hjelpe hverandre både med å komme i gang, og med å komme videre i teksten. De likte «å dele tankene sine med hverandre», sa de, å diskutere og å komme på ting sammen. Men først og fremst snakket de om at det er «mye gøyere» å skrive sammen enn å skrive alene. Utsagnene deres støtter med andre ord opp om forskning som viser betydningen av interaksjon i et trygt sosialt fellesskap i fremmedspråklæringen.

Noen av elevene hadde riktignok motforestillinger. Et par av jentene påpekte at ikke alle er like flinke til å samarbeide, og at det lett kunne bli bare den ene i paret eller gruppa som skrev. En av guttene mente de burde få velge samarbeidspartner(e) selv, ettersom han ikke greide å bidra særlig mye hvis han ble satt i par med ei jente han ikke kjente. Noen av elevene fortalte om uenighet i prosessen, særlig om en idé var god eller ikke.

Per var likevel overbevist om at de aller fleste elevene dro nytte av hverandre, ikke minst for å komme i gang med skrivingen: «Det er vanskelig å komme i gang når en skal skrive en tekst, så hvis den ene har en kime av en idé så spinner den andre videre på det og så bygger det seg opp til et eller annet ok.»

\section{Samarbeid om å skrive for å laere}

I samarbeidet om å produsere en tekst var elevene oftest fornøyd bare de fikk noe ned på papiret. Forslag til en formulering eller et poeng ble så godt som alltid godtatt uten videre diskusjon, og elevene så ut til å bekymre seg lite om det de skrev var tilnærmet korrekt. De hjalp selvsagt hverandre å finne de riktige ordene, og de prøvde å finne ut av utfordringer både når det gjaldt grammatikk og ortografi. Elevene så likevel primært ut til å være opptatt av å uttrykke meningene sine og å få dem til å passe inn i den strukturen som oppgaven krevde. Per snakket om at elevene gikk inn i et «kreativt modus» og påpekte at «når de har skrevet en tekst, så er de liksom så ferdige med den. Det er vanskelig å få dem til å engasjere seg og jobbe mer med den, selv om de vet at de burde.»

Men det var her, i arbeidet med å rette opp og å videreutvikle tekster, at han erfarte at samarbeid virkelig åpner for nye muligheter. Når elevene hadde skrevet noe, ga Per tilbakemelding både på gode ting i teksten og på språkfeil han ønsket at de skulle finne ut av. Han «gulet ut» de passasjene han likte, og mente at det var lurt «å være raus med de gule strekene. Det hjelper nok litt på motivasjonen». Der det var feil han mente elevene burde og kunne finne ut av i fellesskap, satte han en blyantstrek. Han laget også tekster selv, med typiske feil som han ønsket at elevene skulle finne ut av. 
Både Per og jeg ble overrasket over hvor motiverende arbeidet med språklige utfordringer var, og hvor ivrige og engasjerte elevene ble når de arbeidet med slike oppgaver. Det gikk nærmest sport i å være den raskeste til å slå opp i ordboka, og elevene så ut til å vokse flere centimeter både i egne og andres øyne når de for eksempel kunne påpeke at «Det skal være «hates» og ikke «hate» der. For det er jo liksom en han. Sånn «he, she, it hates», vet du». Det var rent rørende å se hvordan de kunne gi hverandre ros, noe elevene i disse gruppene trolig ikke var for bortskjemte med:

Silje: «to» mangler en «W».

Per: ?

Silje: Det skal være «two» som i (viser to fingre)

Per: Å, ja! Silje, you're a genious!

Av og til resonnerte elevene seg riktignok fram til løsninger som var langt fra korrekte, og vi hørte en del diskusjoner som disse:

- Jeg tror det skal være «have» og ikke «has» der.

- Hvorfor det?

- Fordi det er fortid. Sånn preteritum.

- Jeg tror Per sa at det skal være «thinks» og ikke «think» der.

- Hvorfor det da?

- Det er sikkert fordi det er flertall. Når det er mange av en ting, skal det være s.

Elevene hadde åpenbart fått med seg en del grammatisk terminologi, men blandet begreper og regler og hadde store problemer særlig med å identifisere de ulike ordklassene. Men en av fordelene med at de snakket sammen, var at læreren hørte hva de sa og kunne gripe inn. På denne måten kunne han ta del i elevenes «languaging» og tre støttende til slik at de fikk den hjelpen de hadde behov for. Elevene ble også flinkere etter hvert til å dobbeltsjekke løsningene sine med Per, og de virket genuint interesserte i å høre hans forklaringer. Det å oppdage «hull» i egen språkkompetanse (Manchón 2011a) så ut til å være et motiverende steg i læringsprosessen.

Per var helt oppglødd: «Enn at vi ikke har tenkt på dette før. Vi retter og retter, og elevene ser knapt på rettingene og lærer lite eller ingen ting fra den ene teksten til den neste. Når vi setter elevene i par, blir de motivert for å finne ut av feilene, og de jobber kjempegodt sammen.» Per hadde med andre ord funnet en framgangsmåte for å få elever til å merke seg og bearbeide de tilbakemeldingene de får på tekstene sine, noe forskningen påpeker er en forutsetning for at tilbakemeldinger skal ha noen læringseffekt (se for eksempel Sachs \& Polio 2007).

I intervjuene bekreftet elevene at de syntes det var både gøy og lærerikt å samarbeide om å finne og å rette opp feil. De mente at de lærte mye av hverandre og fant flere feil på den måten, fordi de «kunne forskjellige ting». Noen hadde opplevd uenighet og var redde for at partneren kanskje hadde lært dem noe som var feil, men de fleste var overbeviste om at det var større sjanse for «å rette riktig» når de samarbeidet.

Etter hvert som kurset skred fram og de hadde gjort seg noen positive erfaringer, så elevene ut til å bli mer klar over skriving som et redskap for språklæring rent generelt. De påpekte særlig at samarbeidet om skriving gjorde dem bedre til å snakke: «Det henger liksom sammen. Når du blir bedre til å skrive, blir du bedre til å snakke også. Og omvendt». 


\section{Den narmeste utviklingssonen}

Arbeidet med «languaging» viste seg altså å gi Per verdifull innsikt i hvor elevene sto og hva de hadde behov for å lære. En gruppesamtale avslørte for eksempel at Ole, som til vanlig uttrykte svært liten interesse for faget og primært satset på å være klassens klovn, faktisk kunne en hel del engelsk:

Per: Hva er narkoman på engelsk?

Ole: Narco man!

Per (slår opp i ordboka): Drug addict.

Ole: Det var jo det jeg sa!

Jens: Hva heter en uteligger, da?

Ole: Outside sleeper (latter).

- Hobo. She acts like a hobo.

Per (slår opp i ordboka): Det står ikke det her. Dos...

Ole: Du har en sånn dårlig ordbok. Jeg har en bedre en hjemme.

- Hobo. She looks like a hobo.

Jens (skriver).

I intervjuene snakket elevene mye om hvordan de hadde fått ny innsikt i manglene i egen språkkompetanse, og de understreket lærerens betydning i denne prosessen. Per hadde hjulpet dem å finne ut hva de slet med og med å få «tettet hullene», som de sa. Her er et utdrag fra en samtale jeg hadde med elevene på niende trinn etter at deres kurs var avsluttet:

- Jeg visste for eksempel ikke at «I» skulle skrives med stor bokstav.

- Tror de fleste rundt bordet her gjorde det. Jeg har alltid skrevet «I» med liten i. Da jeg fikk beskjed av Per om at jeg skulle skrive med stor I, så fikk jeg mye færre feil.

- Hvis vi ikke kan sånn apostrof og hvis man ikke bruker ordboka siden man ikke skjønner den så fælt, da kan man fort få veldig mange feil, - det kan fort bli opp mot 100 feil. Men nå har vi lært veldig mye.

- Per så jo med en gang hva vi ikke kunne og det har han tetta igjen nå.

- Det er fortsatt mye å lære, men Per var veldig flink.

En hovedgrunn til at Per greide å skaffe seg innsikt i elevenes kompetanse var selvsagt at gruppene var så små. Det gikk raskt for han å se over alle de skriftlige arbeidene, og elevene fikk oftest tilbakemelding i løpet av skriveøkten. Når elevene drev med «languaging»på bakgrunn av en skriftlig tekst, var det også greit å følge med på hva som foregikk. Vi erfarte fordelen som Williams (2012) påpeker ved at elevene forholder seg til et skriftlig produkt som forventes å være tilnærmet korrekt. Samtalene deres dvelte relativt lenge ved hver språklige utfordring, noe som gjorde det mulig for læreren både å lytte til og å engasjere seg i samtalen. Når elevene drev med muntlige aktiviteter, var det mye vanskeligere å følge med, selv om det bare var åtte-ni elever i klasserommet.

\section{Et trygt laeringsfellesskap}

I intervjuene fikk jeg stadig høre om hvor vanskelig elevene syntes det var å være blant de svakeste i en stor klasse. Tre av elevene på åttende trinn sa dette, mens de andre nikket iherdig: 
- Det som er faren er at hvis man ikke er så god i engelsk og sier noe foran hele klassen, et ord helt feil, eller så er det et annet ord, som betyr noe helt annet, og så hvis alle begynner å le da..

- ...da blir man litt redd for å gjøre det igjen.

- Ja, jeg synes også det er litt ekkelt. Jeg liker ikke å få all oppmerksomheten på meg og alle blir helt stille og ser på deg og venter på at du skal svare.

Tre av elevene på tiende trinn uttrykte seg slik:

- Lærerne i sånne store klasser greier ikke å hjelpe oss.

- Oppe i klassen der blir det sånn at læreren hjelper de som er flinke.

- Det som er, læreren går jo til de som er flinke og som bare trenger litt hjelp sånn fort, men vi trenger hjelp som tar litt lenger tid, da, og så går de bare forbi oss.

De undervisningsøktene jeg observerte var imidlertid preget av en atmosfære av trygghet og gjensidig tillit og respekt, og Per hadde helt klart æren for dette. Han framsto som vennlig og åpen, med stor interesse for elevene og deres livsverden. Til å begynne med virket elevene nærmest litt forundret over å bli både sett og hørt, tatt på alvor og akseptert som den de var.

Samtidig var Per faglig ambisiøs på elevenes vegne, og fikk dem til å forstå at kurstilbudet var en unik mulighet for dem til å forbedre seg i engelsk. Han satte opp klare mål for arbeidet, og presiserte at han forventet en ekstra innsats. Elevene på niende trinn, for eksempel, jobbet fram mot tentamen før jul, og målsettingen var å gå opp en karakter sammenlignet med året før. Flere av dem sa at det hadde de faktisk greid.

Alle elevene jeg intervjuet, på alle tre trinn, mente at de virkelig hadde jobbet godt og at det i høy grad var Per sin fortjeneste at de hadde skjerpet seg. Her er to utsagn fra elever på henholdsvis åttende og tiende trinn:

- Vi starta jo selve kurset med at han hilste og ga oss te og kjeks, og det var liksom nok til at vi ville gi alt og være stille og være flinke, så jeg føler at de fleste her har gjort alt det de kan denne høsten og Per har vært en kjempeflott lærer som har hjulpet oss med mye.

- Med en gang man kom inn døra her så hadde man lyst til å jobbe. Mmm. Gledet oss til timen. Ja, vi gjorde det. Erta de andre litt siden de måtte ha naturfag.

En gutt på niende trinn oppsummerte trolig det som var viktigst for de fleste elevene:

Når vi kom inn her så fikk vi te og sånn og så var vi bare vi.

\section{Laererens betydning}

Jeg opplevde Per som en usedvanlig dyktig lærer både hva språk og pedagogikk angår. Han la stor vekt på at elevene skulle venne seg til å slå opp i ordboka og i regelbøkene de hadde laget og prøve å finne ut både av formuleringer og språklige utfordringer på egen hånd. Men når de sto fast eller bega seg ut på ville veier i språkføringen eller i forklaringene sine, var han på pletten, hjalp dem videre og ryddet opp i misforståelsene. I for- eller etterkant av en skrive- $\varnothing \mathrm{kt}$ tok han dessuten ofte tak i utfordringer som gikk igjen. Da forklarte han språklige fenomener med stor faglig innsikt, på en måte som elevene lot til å forstå.

Per snakket konsekvent engelsk i timene og gjorde sitt aller beste for å få elevene til å gjøre det samme. Elevene snakket helst norsk sammen, men når Per ble involvert i deres «languaging» $\mathrm{i}$ arbeidet med en tekst, bidro han alltid til at samtalen dreide over til engelsk. Han la likevel stor vekt på at elevene skulle greie å henge med og oppleve mestring. De 
oppgavene han ga var alltid overkommelige, og elevenes prestasjoner fikk behørig ros og anerkjennelse. Elevene på sin side virket svært fornøyde med seg selv når de hadde skjønt et poeng eller fullført en oppgave slik læreren forventet.

Det var Pers innsikt i forskning som fikk han på tanken om å prøve samskriving og «languaging». Han hadde dessuten nylig lest en av bøkene til Hattie og hadde særlig merket seg poenget med «the power of the peer». I løpet av kursrekkene erfarte han at forskning som påpeker at elever som samarbeider kan dra stor nytte av hverandre har mye for seg: «De tetter hverandres hull. De sier «Ser dette bra ut?» Så sier den andre «Nei, men hva med sånn...» For det første blir jo produktet mye bedre, for det andre tror jeg det skjer mye læring. For når de sitter sammen med en likeverdig, en «peer», så er det et helt annet initiativ til å engasjere seg og gjøre ting så bra som mulig.» Per fortalte at han hadde begynt med samskriving i de ordinære klassene sine også, og at han dessuten hadde inspirert flere andre lærere til å prøve samskriving og «languaging» i sine klasser.

\section{Oppsummering}

Både elevene, læreren og jeg som følgeforsker erfarte at samarbeid om skriving kan være en fruktbar arbeidsmetode. Elevene ga uttrykk for at samskriving var både nyttig og «g $\varnothing \mathrm{y} », \mathrm{og}$ observasjonene viste at elevene var ivrige og jobbet godt. De hjalp hverandre å laere å skrive, - med å finne ut hvilket innhold de skulle skrive om og hvordan de skulle bygge opp en tekst. Ettersom elever gjerne ønsker å bli fortest mulig ferdig og ofte er fornøyd bare de har skrevet noen få linjer, benyttet læreren seg ofte av skriverammer som ga støtte til skrivingen og ansporet dem til å utdype poengene sine.

I tråd med Swain \& Lapkins (1995) «output hypothesis» la jeg merke til at elevene stadig sto overfor valg når de skulle formulere seg, og de ble oppmerksomme på «hull» i sin egen kompetanse (Manchón 2011a). Når de arbeidet i par eller grupper på tre måtte de sette ord på utfordringene sine og gjerne forklare språklige valg både for seg selv og andre. Det er grunn til å tro at slik «languaging» (Swain 2006) bidrar til økt forståelse, i tillegg til at elevene trolig husker det de har jobbet med bedre.

Det er selvsagt ikke noe klart skille mellom å lare å skrive og å skrive for å lare, ettersom all produksjon av tekst åpenbart kan bidra til elevens språklæring (Manchón 2011a). Noen av aktivitetene jeg observerte var likevel mer fokusert på språklæring enn andre. Det gjaldt særlig oppgaver der elevene skulle bearbeide eller rette opp en tekst. Disse oppgavene tok som regel utgangspunkt i tekster som elevene hadde produsert selv, men også i tekster som læreren hadde laget med tanke på å illustrere språkfeil som gikk igjen i elevgruppa. Læreren la vekt på å påpeke vellykkete så vel som mindre vellykkete sider ved elevenes tekster, og det var tydelig at hans ros og anerkjennelse ga elevene det pågangsmotet de trengte. Han indikerte også tydelig hva som burde rettes opp i tekstene.

Elevene gikk løs på oppgavene med iver og innsatsvilje, og det var ikke sjelden de ga uttrykk for aha-opplevelser og lyste opp over å ha forstått et språklig fenomen. Jeg observerte at det ble en ro over arbeidet og at elevene jobbet grundigere med språket når de tok utgangspunkt i en skriftlig og ikke en muntlig tekst, slik Williams (2012) påpeker. De la vekt på å rose hverandre og anerkjenne hverandres bidrag.

Ettersom det kan være vanskelig å få elever til å bearbeide egne tekster og å reflektere over egne språklige ferdigheter, opplevde både læreren og jeg dette samarbeidet som litt av et columbi egg. Elevene hadde klart definerte oppgaver, de arbeidet med dem i et sosialt og trygt læringsfellesskap, og de opplevde mestring. Læreren spilte en sentral rolle i dette samarbeidet. Det var han som formulerte motiverende og overkommelige oppgaver, ga faglig støtte og, ikke minst, sørget for at det var en inkluderende og god atmosfære i klasserommet.

Vi erfarte med andre ord til fulle at Hattie (2009) sine tanker om «The power of the peer» har mye for seg. Samtidig er det ikke sikkert at denne kraften er like mye verdt om den 
ikke kombineres med «The power of the teacher». Når elevene trivdes med kurstilbudet, jobbet godt og opplevde at de gjorde betydelige framskritt, var dette etter mitt syn i stor grad et resultat av at læreren hadde høy faglig og didaktisk kompetanse og en måte å være på som gjorde at elevene likte og hadde tillit til ham. I tillegg kan trolig «The power of the system» føyes til som en avgjørende faktor. Elevene ble undervist i små grupper, der formålet nettopp var at de skulle føle seg trygge og bli møtt der de var, og der hver eneste time hadde hver enkelt elevs faglige framgang som uttalt målsetting.

Denne undersøkelsen knytter an til tidligere forskning som viser betydningen av at fremmedspråkelever produserer språk selv og at de reflekterer over egen språkkompetanse ved hjelp av «languaging». Som tidligere forskning peker den også på skriving som en spesielt godt egnet aktivitet for språklæring og, ikke minst, på betydningen av et trygt læringsmiljø med «peers» som kan fungere både som et sosialt og et faglig nettverk. Det som kan sies å være nytt i Pers fors $\varnothing \mathrm{k}$, i alle fall i en norsk sammenheng, er at han tok utgangspunkt i og kombinerte alle disse ulike perspektivene.

For Per og elevene hans var samarbeid om ulike typer skriveoppgaver en helt ny måte å organisere undervisningen på, og erfaringene fra fors $\varnothing$ ket bidro til ny innsikt $\mathrm{i}$ det potensialet som ligger både i samarbeidsformen og i det å skrive. Per benyttet seg av denne innsikten i arbeidet med andre klasser på skolen, og han delte den med kollegene sine. Med tanke på hvor lite forskning som er gjort i Norge på skriving som en grunnleggende ferdighet, synes det betimelig å bringe innsikten videre også. Selv om de funnene som er beskrevet her er gjort i en spesiell opplæringssituasjon, peker undersøkelsen etter mitt syn på prinsipper så vel som konkrete arbeidsformer som kan benyttes i de fleste klasserom.

\section{Litteratur}

Ali, Amira. 2013. Scaffolding Writing Strategies of EFL Students: A Suggested Program based on Scaffolding Writing Strategies to Develop EFL Writing. LAP LAMBERT Academic Publishing.

Drew, I. 1998. Future Teachers of English: A Study of Competence in the Teaching of Writing. Kristiansand: Høyskoleforlaget.

Gregory, A., \& Ripski, M. 2008. Adolescent trust in teachers: Implications for behavior in the high school classroom. School Psychology Review 37 (3), 337-353.

Hattie, J. A. C. 2009. Visible Learning. Oxon and New York: Routledge.

Hyland, K. 1996. Second Language Writing. Cambridge: Cambridge University Press.

Hyland, K. \& F. Hyland (red). 2006. Feedback in Second Language Writing. Contexts and Issues. Cambridge University Press.

Hyland, F. 2011. The language learning potential of form-focused feedback on writing: Students and teachers' perceptions. I Manchón, R. (red). 2011b, 159-180.

Kroll, B. (red). 1990. Second language writing: research insights for the classroom. Cambridge University Press.

Langseth, I. 2012. Literacy i språkfagene: Erfaringer fra et kompetanseutviklingsprosjekt. Nordic Journal of Modern Language Methodology, Vol. 1, No. 1, 1-21.

Larsen, A. B. 2009. Content in Nordic Pupil Narratives in Instructed EFL: A Norwegian Perspective. Universitetet i Troms $\varnothing$ : Avhandling for graden $\mathrm{PhD}$.

Lewis, M. \& Wray, D. 2002. Writing Frames. University of Reading: National Centre for Language and Literacy.

Lia, H. B. 2001. Some Aspects of the Teaching of Writing in English as a Foreign Language. Universitetet i Oslo: Upublisert hovedfagsoppgave.

Lightbown, P. M. \& Spada, N. 2006. How Languages are Learned. 3rd edition. Oxford University Press. 
Lund, R. 2013. Skriveoppgaver i to engelsklæreverk for mellomtrinnet. I Askeland, N., E. Maagerø \& B. Aamotsbakken (red). 2013. Lareboka. Studier i ulike laereboktekster, 83101. Trondheim: Akademika forlag.

Manchón, R. M. (red). 2009. Writing in Foreign Language Contexts. Learning, Teaching, and Research. Bristol, Buffalo, Toronto: Multilingual Matters.

Manchón, R. M. 2011a. Writing to learn the language. I Manchón, R. 2011b, 61-84.

Manchón, R. M. (red). 2011b. Learning-to-Write and Writing-to-Learn in an Additional Language. Amsterdam: John Benjamins.

Oddvik, M. 2011. Many People, Many Minds: Collaborative Writing Using CSCL in the ESL Classroom. NTNU: Upublisert masteroppgave.

Raaen, G. F. \& T. Guldal. 2012. Basic skills: Orthography and sentence complexity in written English from grades 7 to 10. I Hasselgren, A, I. Drew \& B. Sørheim (red). The Young Language Learner, 101-117. Bergen: Fagbokforlaget.

Roeser, R. W., Eccles, J. S., \& A. J. Sameroff. 2000. School as a context of early adolescents' academic and social-emotional development: A summary of research findings. The Elementary School Journal 100 (5), 443-471.

Sachs, R. \& C. Polio 2007. Learners' uses of two types of written feedback on a L2 writing revision task. Studies in Second Language Acquisition, 29, 67-100.

Shehadeh, A. 2011. Effects and student perceptions of collaborative writing in L2. Journal of Second Language Writing 20, 286-305.

Storch, N. 2005. Collaborative writing: Product, process, and students' reflections. Journal of Second Language Writing 14, 153-173.

Swain, M. 2006. Languaging, agency and collaboration in advanced second language proficiency. I Byrnes, H. (red). Advanced language learning. The contribution of Halliday and Vygotsky, 95-108. London and New York: Continuum.

Swain, M. \& S. Lapkin. 1995. Problems in output and the cognitive processes they generate: A step toward language learning. Applied linguistics 16, 371-391.

Truscott, J. 1996. The case against grammar correction in L2 writing classes. Language Learning 46, 327-369.

Truscott, J. 2007. The effect of error correction on learners' ability to write accurately. Journal of Second Language Writing 16, 255-272.

Utdanningsdirektoratet. 2013. Læreplan i engelsk. Lastet ned 03.05.15 fra http://www.udir.no/k106/ENG1-03/Hele/Grunnleggende_ferdigheter/

Vygotsky, L. 1978. Mind in Society. Cambridge, MA: Harvard University Press.

Wigglesworth, G. \& N. Storch 2012. What role for collaboration in writing and writing feedback. Journal of Second Language Writing 21, 364-374.

Williams, J. 2012. The potential role(s) of writing in second language development. Journal of second language writing 21, 321-331. 